\title{
When Much Is Too Much-Compared to Light Exercisers, Heavy Exercisers Report More Mental Health Issues and Stress, but Less Sleep Complaints
}

\author{
Sanobar Golshani ${ }^{1}$, Ali Najafpour ${ }^{2}$, Seyed Sepehr Hashemian ${ }^{3}{ }^{(D}$, Nasser Goudarzi ${ }^{4}$, Fatemeh Shahmari ${ }^{1}$, \\ Sanam Golshani ${ }^{5}$, Masthaneh Babaei ${ }^{6}{ }^{\mathbb{D}}$, Kimia Firoozabadi ${ }^{6}$, Kenneth M. Dürsteler ${ }^{7,8} \mathbb{\infty}$, \\ Annette Beatrix Brühl ${ }^{9}{ }^{\circ}$, Jalal Shakeri ${ }^{1}$, Serge Brand ${ }^{9,10,11,12,13, * \mathbb{C}}$ and Dena Sadeghi-Bahmani ${ }^{9,10,14} \mathbb{C}$
}

check for updates

Citation: Golshani, S.; Najafpour, A.; Hashemian, S.S.; Goudarzi, N.;

Shahmari, F.; Golshani, S.; Babaei, M.; Firoozabadi, K.; Dürsteler, K.M.; Brühl, A.B.; et al. When Much Is Too Much-Compared to Light Exercisers, Heavy Exercisers Report More Mental Health Issues and Stress, but Less Sleep Complaints. Healthcare 2021, 9 , 1289. https://doi.org/10.3390/ healthcare 9101289

Academic Editors: Filipe

Manuel Clemente and

Herbert Löllgen

Received: 4 July 2021

Accepted: 24 September 2021

Published: 28 September 2021

Publisher's Note: MDPI stays neutral with regard to jurisdictional claims in published maps and institutional affiliations.

Copyright: (c) 2021 by the authors. Licensee MDPI, Basel, Switzerland. This article is an open access article distributed under the terms and conditions of the Creative Commons Attribution (CC BY) license (https:/ / creativecommons.org/licenses/by/ $4.0 /)$.
1 Kermanshah University of Medical Sciences, Kermanshah 6714869914, Iran; snb.gln@gmail.com (S.G.); fatemesh9373@gmail.com (F.S.); jshakerimd@yahoo.com (J.S.)

2 Student Research Committee, Faculty of Medicine, Kermanshah University of Medical Sciences, Kermanshah 6714869914, Iran; ali98aaa@yahoo.com

3 Department of Psychology, Allameh Tabataba'i University, Tehran 1489684511, Iran; sepehr.hashemian@gmail.com

4 Department of Psychiatry, AJA University of Medical Sciences, Tehran 1411718541, Iran; nassergoodarzi@yahoo.com

5 Department of Cardiology, AJA General Hospital, Kermanshah 6714869914, Iran; Sanamgolshani7@gmail.com

6 School of Medicine, Urmia University of Medical Sciences, Urmia 5714783734, Iran; mastanebabai91@gmail.com (M.B.); kimia.firoozabadi65@gmail.com (K.F.)

7 Psychiatric Clinics, Division of Substance Use Disorders, University of Basel, 4002 Basel, Switzerland; Kenneth.Duersteler@upk.ch

8 Center for Addictive Disorders, Department of Psychiatry, Psychotherapy and Psychosomatics, Psychiatric Hospital, University of Zurich, 8001 Zurich, Switzerland

9 Center for Affective-, Stress- and Sleep Disorders (ZASS), Psychiatric Clinics (UPK), University of Basel, 4002 Basel, Switzerland; Annette.Bruehl@upk.ch (A.B.B.); dena.sadeghibahmani@upk.ch (D.S.-B.)

10 Sleep Disorders Research Center, Kermanshah University of Medical Sciences, Kermanshah 6714869914, Iran

11 Substance Abuse Prevention Research Center, Kermanshah University of Medical Sciences, Kermanshah 6714869914, Iran

12 Department of Sport, Exercise, and Health, Division of Sport Science and Psychosocial Health, University of Basel, 4052 Basel, Switzerland

13 Department of Psychiatry, School of Medicine, Tehran University of Medical Sciences, Tehran 1417466191, Iran

14 Department of Psychology, Stanford University, Stanford, CA 94305, USA

* Correspondence: serge.brand@upk.ch

\begin{abstract}
Background: Physical inactivity has become a global somatic and mental health issue. To counterbalance, promoting regular physical activity appears plausible, above all among adults, where physical inactivity is particularly high. However, some, but sparse, research also indicates that excessive exercising might be associated with unfavorable mental health dimensions. Here, we tested the hypothesis that excessive exercising was associated with more mental health issues. To this end, we assessed mental health issues, stress, mental toughness, and sleep disturbances among heavy and light adult exercisers. Methods: A total of 200 adults (mean age: 35 years; $62 \%$ females) took part in the study. Of those, 100 were heavy exercisers (18-22 h/week), and 100 were light exercisers (1-6 h/week). Participants completed questionnaires covering sociodemographic information, mental health issues, perceived stress, mental toughness, and sleep disturbances. Results: Compared with light exercisers, heavy exercisers reported higher mental health issues, more stress, but also higher mental toughness scores and less sleep disturbances. Higher age, lower mental toughness scores, heavy exerciser-status, and more sleep disturbances predicted higher mental health complaints. Conclusions: Compared with light exercising, heavy exercising might be associated with more mental health issues. As such, it appears that the association between exercise frequency, intensity, and duration and psychological well-being might be related to an optimum point, but not to a maximum point. In a similar vein, heavily exercising athletes, their coaches, parents, and
\end{abstract}


representatives of sports associations should get sensitized to possible adverse psychological effects of excessive physical activity patterns.

Keywords: heavy and light exercisers; mental toughness; stress perception; sleep quality; general health

\section{Introduction}

Approximately $31 \%$ of the global population aged $\geq 15$ years engages in insufficient physical activity, and such kind of low activity is known to contribute to the death of approximately 3.2 million people every year [1-4]. To illustrate: Adult people in the USA spend $55 \%$ of their waking time ( $7.7 \mathrm{~h}$ a day) engaged in sedentary behaviors; people in European countries spend $40 \%$ of their leisure time ( $2.7 \mathrm{~h}$ a day) watching television [5]. An increasing pattern of sedentary lifestyle and insufficient physical activity (IPA) were associated with poor psychological functioning among adolescents aged 11-17 years [6] and adults aged 18 to 80 years [7]. Korean adults reported $8.3 \mathrm{~h}$ of sedentary time a day [8]. Importantly, among Koreans aged 50 years and older, longer sitting time and lower physical activity indices were associated with chronic low back pain [9] and the risk of cardiovascular diseases at long-term [10]. Therefore, both reducing sedentary behaviors and increasing physical activity appeared to be important factors to promote public health [11]. Not surprising, mental health issues [12] such as stress [13] and sleeping problems [14] were tightly associated with low physical activity patterns $[15,16]$. We took these observations into account and investigated the associations between mental health issues, stress, mental toughness, and sleep among adult heavy and light exercisers.

In a very similar vein, Iran is among the countries with medium to high insufficient IPA indices in global reports: In 2011, national reports revealed an IPA rate of $39.1 \%$ among the adult population [17]. Eight years later, the prevalence of IPA raised to $54.7 \%$, with a considerable difference between the two genders (males: 45.3\%, females: 61.9\%) [18]. In this view, physical inactivity is particularly challenging among adults in their thirties, as this period of life is a psychosexually, psychosocially, and economically demanding developmental stage of adulthood; as such, physical inactivity appears to affect the economically most active population [19] and the population with the highest pressure to prevail and assert for successful mating [20-22]. We took this observation into consideration and assessed mental health issues, stress, and sleep disturbances among Iranian adult heavy and light exercisers in this age range.

While there is extant literature to show that physical inactivity is related to higher mental health issues (see above), there is also extant literature to show the favorable association between regular physical activity patterns and lower mental health complaints (e.g., [23]). Such favorable associations have been observed among children [24-28], adolescents [6,29-35], and adults [8,13,36-50], and among clinical samples, such as individuals with major depressive disorder [32,51-68] or multiple sclerosis [69-83]. And such observations hold also true as regards the associations between higher physical activity patterns and better coping with stress [60,84-90]. More generally, higher physical activity patterns were associated with more restoring sleep, lower perceived stress levels, and higher mental toughness scores. As such, the results mentioned above suggest that "more (physical activity) leads to more (psychological well-being)".

However, such claims have been challenged: Sparse, inconsistent, but increasing data show that excessive exercising might be associated with symptoms of mental health issues [91-98]. Similarly, at least among adolescents and longitudinally, physical activity patterns were completely unrelated to participants' mental health [99], challenging the claim that, almost by nature, higher physical activity patterns lead more favorable mental health. In this regard, we also note that $12-14 \%$ of promising junior elite athletes reported symptoms of burnout $[100,101]$. 
Thus, recent research points out to a dilemma: While physical inactivity is related to more physical and mental health issues, this might be associated with excessive exercising, too. Typically, psychological dimensions related to physical activity patterns are mental health, mental toughness, perceived stress, and sleep quality. Given this background and given that, to our knowledge, data from Iran on this topic are missing so far, we assessed mental health, stress, mental toughness, and sleep disturbances as a proxy for psychological functioning among heavy exercisers ( $3 \mathrm{~h} /$ day; 6 days/week), compared with light exercisers (1-6 h/week).

Almost by definition, a personality trait tightly related to sports performance is mental toughness. Indeed, there is sufficient evidence of a favorable association between higher physical activity patterns and higher mental toughness scores [34,101-118]. Here, mental toughness is understood as the personality trait conferring the ability to control one's life and emotions, to perceive demands and expectations as a challenge (as opposed to a threat), to stay committed to one's own aims and goals, and to have confidence both in one's abilities and in stable relationships. This is labelled the "Four C model" [119]. Importantly, in the area of sports performance, mental toughness is associated with persistence, with being better prepared to deal with challenges, and with finding a way to succeed despite setbacks [110,120-122]. In this line, mental toughness favorably moderated the relation between physical activity intention and physical activity behavior. Further, it appears that the origins of mental toughness go back to pre-school age [123]. However, we also note that a recent systematic review showed that despite the widely used term of mental toughness as a personality trait important for performance in the field of sport, no uniform and coherent definition of mental toughness appears to be available [124].

Thus, while the general setup is that higher mental toughness scores are associated with better psychological functioning and higher physical activity performance, on the flip side, there are also some critical statements: Specifically, athletes with high mental toughness scores might be at risk of overtraining [125] and of displaying also negative personality traits, such as the so-called dark trait [126-128]. Similarly, athletic identity was associated with higher symptoms of depression, mental toughness, over-adherence to physical activity intensity, playing through pain, and injury severity [129]. We took these conflicting results into consideration and asked if heavy exercisers reported higher mental toughness scores, compared with light exercisers.

Lastly, an important factor for both physical and mental health is restoring sleep. Again, there is sufficient evidence on the associations between restoring sleep and higher physical activity patterns: Interventional [130,131] and associative studies [33,132-137] suggested that higher physical activity levels favorably impacted on sleep quality; though, bi-directional and reciprocal processes appeared to be most plausible $[138,139]$. We considered these observations and asked if heavy exercisers reported less sleep disturbances, compared with light exercisers.

Overall, there is sufficient evidence that physical inactivity is causally related to a broad variety of non-communicable diseases among children, adolescents, and adults. In contrast, regular physical activity levels are associated with a broad range of mental health indices, such as lower risk of psychiatric issues, along with lower stress, better sleep, and higher mental toughness scores as a proxy for high psychological functioning. On the flip side, there is also some, also inconsistent, evidence that heavy exercising might be associated with mental health issues, as excessive mental toughness scores might also lead to adverse health effects. Further, to our knowledge, research on these topics has not been conducted so far among Iranian adults.

As a consequence, the aims of the present study were to address these issues, and given these backgrounds, the following two hypotheses and two research questions were formulated:

First, based on previous research [33,132-140], we assumed that compared with light exercisers, heavy exercisers would report less sleep complaints. 
Second, following others [60,84-90], we assumed that compared with light exercisers, heavy exercisers would report lower scores of perceived stress.

Next, the first research question asked was if and to what extent heavy exercisers would report more favorable or more unfavorable mental health scores and mental toughness scores, always compared with light exercisers. This research question is based on more recent research on the adverse effects of excessive exercising on mental health [91-98].

The second research question asked was if sleep, stress, mental toughness, and exercising status could predict mental health issues. To this end, we assessed mental health, perceived stress, mental toughness, and sleep complaints of heavy and light adult Iranian exercisers.

We hold that the results might be of clinical and practical importance: If it turns out that heavy exercising is also associated with adverse health issues, then exercisers, coaches, parents, and representatives of sports associations should get sensitized to possible adverse psychological disadvantages of heavy exercising.

\section{Methods}

\subsection{Procedure}

Adults attending regular physical activities were approached and asked to participate in the present study on physical activity patterns and psychological functioning. Participants were fully informed about the aims of the study and the secure and anonymized data handling. Thereafter, participants signed a written informed consent and completed a series of self-rating questionnaires on mental health, perceived stress, and sleep (see details below). The ethical committee of Kermanshah University of Medical Science, Kermanshah, Iran (Ethics ID: IR. KUMS. REC. 1398. 583) approved the study, which was performed in accordance with the seventh and current [141] edition of the Declaration of Helsinki.

\subsection{Participants}

We selected adults with heavy and light exercising patterns. The procedure was as follows: By referring to the Kermanshah Sports Federation (Kermanshah, Iran), people who exercised heavily and people who exercised lightly, in all sports, such as running, tennis, martial arts, swimming, aerobics, football, basketball, volleyball, and handball, were selected with the same age and, if possible, the same gender.

Inclusion criteria for heavy exercisers were: (1) age between 18 and 65 years; (2) for the last two years, exercising at least six days a week, for at least $3 \mathrm{~h}$ a day, both as selfreported and as ascertained by professional coached from the Iranian Sports Federation; (3) compliance with the study conditions; (4) signed written informed consent. Exclusion criteria were: (1) psychiatric issues; to this end, trained psychiatrists and clinical psychologists performed face-to-face clinical interviews [142] based on the DSM-5 [143]; (2) regular intake of mood-altering, sleep-altering, or performance-enhancing substances, such as psychoactive medications or illicit drugs (e.g., steroids, amphetamines, anabolic substances); (3) severe physical issues, such as injuries, chronic inflammations, autoimmune diseases, musculoskeletal issues, chronic pain and similar, as assessed via a brief medical interview by trained medical doctors.

Inclusion and exclusion criteria for light exercisers were identical to the inclusion and exclusion criteria of heavy exercisers, with the following difference: exercising between one to three days a week, for one to two hours a day as self-reported and as ascertained by professional coaches from the Iranian Sports Federation.

\subsection{Measures}

\subsubsection{Sociodemographic Information}

Participants reported their age (years), gender (male, female), civil status (single; married), current job position (employed; unemployed), and highest educational level (high school diploma; higher educational level). 


\subsubsection{General Health Questionnaire}

To assess mental health issues, the Farsi version [144] of the General Health Question naire-28 [145] was employed. The Farsi version had psychometrically satisfying indices (Cronbach's alphas for somatization, anxiety, social functioning, depression, and the overall score: $0.70,0.84,0.93,0.92,0.85$, respectively). Typical items are somatic symptoms (items 1-7), anxiety/insomnia (items 8-14), social dysfunction (items 15-21), or severe depression (items 22-28). Typical items are: "Have you recently been feeling perfectly well and in good health?"; "Have you recently lost much sleep over worry?"; "Have you recently been managing to keep yourself busy and occupied?"; "Have you recently felt constantly under strain? ". Answers were given on 4-point Likert scales ranging from 0 (not at all) to 3 (much more than usual). The following sub-scores were calculated: somatization, anxiety, social function, depression, and the total score. Higher sum scores reflect more impaired or more distressed general health (Cronbach's alpha: 0.89).

\subsubsection{Mental Toughness Questionnaire}

The Farsi version $[115,116,126,146]$ of the Mental Toughness Questionnaire [119,147] was employed. The Farsi version had psychometrically satisfying indices (lowest Cronbach's alpha $=0.80$ ). Here, we used the shortened questionnaire with 18 items, which provides a global mental toughness score. Typical items are: "Challenges usually bring out the best in me"; "I generally feel in control"; "Even when under considerable pressure I usually remain calm". Answers on the MTQ18 were given on 5-point Likert-type scales ranging from $1=$ "strongly disagree" to $5=$ "strongly agree." Items were summed to obtain the overall score, with higher scores reflecting a higher mental toughness (Cronbach's alpha: 0.89 ).

\subsubsection{Perceived Stress}

To assess perceived stress, the Farsi version [148,149] of the Perceived Stress Scale [150] was employed. The Farsi versions had psychometrically satisfying indices (lowest Cronbach's alpha $=0.72$ ). Typical items are: "In the last month, how often have you been upset because of something that happened unexpectedly?"; "In the last month, how often have you been angered because of things that were outside of your control?"; In the last month, how often have you been able to control irritations in your life?" (reversed scaling). Answers were given on 5-points Likert scales ranging from 1 (never) to 5 (almost always), with higher scores reflecting higher perceived stress (Cronbach's alpha: 0.89).

\subsubsection{Sleep Disturbances}

To assess sleep disturbances, the Farsi version [151-155] of the Pittsburgh Sleep Quality Index [156] was employed. The Farsi versions had psychometrically satisfying indices (lowest Cronbach's alpha $=0.77)$. As mentioned elsewhere [151], the questionnaire consists of 18 items, which are summed up to the following dimensions: (1) subjective sleep quality; (2) sleep latency; (3) sleep duration; (4) habitual sleep efficiency; (5) sleep disturbances; (6) sleeping medication; (7) daytime dysfunction. Each component score has a possible range of 0 to 3, with higher scores indicating poorer sleep. Further, the PSQI global score of sleep quality ranges from 0 to 21 . A sum score of 5 points or higher reflects sleep disturbances (Cronbach's alpha: 0.81).

\subsection{Statistical Analysis}

First, the inspection with a series of Kolmogorov-Smirnov tests showed that outcome variables were normally distributed.

With a $t$-test and a series of $\chi^{2}$-tests, we compared sociodemographic information between heavy and light exercisers.

With a series of Pearson's correlations, associations between age, general health, perceived stress, mental toughness, and sleep complaints were calculated for the whole sample and also separately for heavy and light exercisers. 
A series of $t$-tests was performed to compare means of perceived stress, mental toughness, and sleep complaints between heavy and light exercisers.

A series of multivariate ANOVAs was performed with the factor exerciser status (light; heavy) and dimensions of general health (somatization, anxiety, social function, depression, general health score) as dependent variables.

To predict general health, a multiple regression analysis was performed. Preliminary conditions to perform multiple regression analyses were met [157-159]: $N=200>100$; predictors explained the dependent variables $\left(R=0.683, R^{2}=0.466\right)$; the number of predictors: $8 ; 10 \times 8=80<\mathrm{N}(200)$, and the Durbin-Watson coefficient was 1.83, indicating that the residuals of the predictors were independent. Furthermore, the variances inflation factors (VIF) were between 1.03 and 1.18, while there are no strict cut-off points to report the risk of multicollinearity, VIF < 1 and VIF $>10$ indicate multicollinearity $[158,159]$.

To test for possible interaction effects within the multiple regression model, we followed Aiken and West [160], who proposed to multiply the residuals of the independent factors and to model this product as a function of the categories of one factor. Specifically, we multiplied the residuals of the factors exercise status and sleep disturbances; next, the product was entered into the multiple regression model as a further factor. Lastly, to understand the nature and direction of the interaction, a scatter plot was created with the dimensions exercise status and general health, moderated by the category of sleep disturbances (no vs. yes).

Effect sizes were reported as follows: For $t$-tests, Cohen's ds were calculated, with the following cut-off values: trivial (ds: 0-0.19), small (ds: 0.20-0.49), medium (ds: 0.50-0.79), or large (ds: 0.80 and greater). For F-tests, effect sizes were reported as partial eta-squared $\left[\eta_{p}{ }^{2}\right]$ ) and interpreted as follows: trivial (T) $0.019<\eta_{p}{ }^{2}$; small (S) $=0.020 \leq \eta_{p}{ }^{2} \leq 0.059$, medium $(\mathrm{M})=0.06 \leq \eta_{p}{ }^{2} \leq 0.139$, or large $(\mathrm{L})=\eta_{p}{ }^{2} \geq 0.14[161,162]$.

The level of significance was set at alpha $<0.05$. All statistical procedures were performed with the SPSS ${ }^{\circledR} 25.0$ (IBM Corporation, Armonk, NY, USA) for Apple Mac ${ }^{\circledR}$.

\section{Results}

\subsection{General Information}

Table 1 provides the descriptive and inferential statistical overview of sociodemographic information on heavy and light exercisers.

Table 1. Overview of sociodemographic information on heavy and light exercisers.

\begin{tabular}{|c|c|c|c|c|}
\hline & & \multicolumn{2}{|c|}{ Exercisers } & \multirow[t]{2}{*}{ Statistics } \\
\hline Dimensions & & Heavy & Light & \\
\hline \multirow[t]{2}{*}{$\mathrm{N}$} & & 100 & 100 & \\
\hline & & $\mathrm{M}(\mathrm{SD})$ & $\mathrm{M}(\mathrm{SD})$ & \\
\hline \multirow[t]{2}{*}{ Age (years) } & & $35.45(13.48)$ & 34.17 (12.30) & $t(198)=0.04$ \\
\hline & & $\mathrm{N}(\%)$ & $\mathrm{N}(\%)$ & \\
\hline Gender & $\begin{array}{l}\text { Male } \\
\text { Female }\end{array}$ & $\begin{array}{l}\text { (34) } 34 \\
\text { (66) } 66\end{array}$ & $\begin{array}{l}\text { (42) } 42 \\
(58) 58\end{array}$ & $\chi^{2}(\mathrm{~N}=200 ; \mathrm{df}=1)=1.36, p=0.24$ \\
\hline Civil status & $\begin{array}{l}\text { Single } \\
\text { Married }\end{array}$ & $\begin{array}{l}\text { (49) } 49 \\
\text { (51) } 49\end{array}$ & $\begin{array}{l}\text { (51) } 51 \\
(49) 49\end{array}$ & $\chi^{2}(\mathrm{~N}=200 ; \mathrm{df}=1)=0.80, p=0.78$ \\
\hline Employment & $\begin{array}{c}\text { Employed } \\
\text { Unemployed }\end{array}$ & $\begin{array}{l}\text { (47) } 47 \\
(53) 53\end{array}$ & $\begin{array}{l}\text { (50) } 50 \\
\text { (50) } 50 \\
\end{array}$ & $\chi^{2}(\mathrm{~N}=200 ; \mathrm{df}=1)=0.18, p=0.67$ \\
\hline Educational level & $\begin{array}{l}\text { High school diploma } \\
\text { Higher education }\end{array}$ & $\begin{array}{l}53(27) \\
47(23)\end{array}$ & $\begin{array}{l}55(28) \\
45(22)\end{array}$ & $\chi^{2}(\mathrm{~N}=200 ; \mathrm{df}=1)=0.19, p=0.86$ \\
\hline
\end{tabular}

As shown in Table 1, no descriptively or statistically significant differences of sociodemographic data were observed between heavy and light exercisers. 
3.2. Descriptive Statistics and Correlations between Age, General Health, Perceived Stress, Mental Toughness, and Sleep Disturbances for the Whole Group and Separately for Heavy and Light Exercisers

Table 2 provides the descriptive statistics and correlations between age, general health, perceived stress, mental toughness, and sleep disturbances for the whole group and separately for heavy and light exercisers.

Table 2. Descriptive statistics and Pearson correlation coefficients between age, general health, perceived stress, mental toughness, and sleep disturbances for the whole group and separately for heavy and light exercisers.

\begin{tabular}{|c|c|c|c|c|c|c|c|c|c|c|c|c|c|c|c|}
\hline \multirow{2}{*}{\multicolumn{2}{|c|}{ Dimensions $T$}} & \multicolumn{2}{|l|}{ Age } & \multicolumn{3}{|c|}{ GHQ } & \multicolumn{3}{|c|}{ PSS } & \multicolumn{3}{|c|}{ MT } & \multicolumn{3}{|c|}{ PSQI } \\
\hline & & HE & LE & $\mathrm{T}$ & HE & LE & $\mathrm{T}$ & HE & LE & $\mathrm{T}$ & HE & LE & $\mathbf{T}$ & HE & LE \\
\hline Age & - & - & - & $\underset{* *}{0.31}$ & $\begin{array}{l}0.50 \\
* * *\end{array}$ & 0.05 & 0.02 & -0.13 & 0.14 & $-\underset{* *}{-0.26}$ & $\underset{* * *}{-0.36}$ & -0.17 & $\begin{array}{l}0.25 \\
* *\end{array}$ & $\begin{array}{c}0.54 \\
* * *\end{array}$ & -0.08 \\
\hline GHQ & - & - & - & - & - & - & -0.03 & $\begin{array}{c}0.43 \\
* * *\end{array}$ & 0.23 & -0.09 & $\begin{array}{c}-0.29 \\
* *\end{array}$ & 0.12 & $\begin{array}{l}0.64 \\
* * *\end{array}$ & $\begin{array}{c}0.67 \\
* * * *\end{array}$ & $\begin{array}{c}0.69 \\
* * *\end{array}$ \\
\hline PSS & - & - & - & - & - & - & - & - & - & $\underset{* *}{-0.26}$ & $\underset{*}{-0.17}$ & $\underset{* *}{-0.24}$ & -0.09 & $\underset{* *}{0.22}$ & 0.06 \\
\hline MT & - & - & - & - & - & - & - & - & - & - & - & - & -0.11 & $\underset{* * *}{-0.31}$ & 0.11 \\
\hline PSQI & - & - & - & - & - & - & - & - & - & - & - & - & - & - & - \\
\hline $\mathrm{M}$ & 35.17 & 35.17 & 34.35 & 20.52 & 21.82 & 19.21 & 34.57 & 36.06 & 33.09 & 31.30 & 32.51 & 30.09 & 4.81 & 4.54 & 5.07 \\
\hline SD & (13.48) & $(12.93)$ & $(13.58)$ & 19.62 & 12.59 & 8.05 & 4.93 & 4.17 & 5.20 & 5.98 & 5.57 & 6.16 & 2.52 & 2.48 & 2.54 \\
\hline
\end{tabular}

Notes: ${ }^{*}=p<0.05 ;{ }^{* *}=p<0.01 ;{ }^{* * *}=p<0.001 ; \mathrm{T}=$ total sample; HE = heavy exercisers; LE = light exercisers; GHQ = general health questionnaire; higher scores reflect a more impaired health; PSS = perceived stress scale; a higher score reflects a higher perceived stress; MT = mental toughness; a higher score reflects a more pronounced mental toughness; PSQI = Pittsburgh sleep quality index; a higher score reflects a more disturbed sleep. $\mathrm{M}=$ mean; $\mathrm{SD}$ = standard deviation.

As regards the whole sample, a higher age was associated with higher general health complaints, lower mental toughness scores, and higher sleep disturbances, while age was not associated with perceived stress. Further, higher general health complaints were associated with higher sleep disturbances, while general health was not associated with perceived stress and mental toughness. Higher mental toughness scores were associated with lower sleep complaints.

As regards heavy exercisers, a higher age was associated with higher general health complaints, lower mental toughness, and higher sleep complaints, while age was not associated with perceived stress. Higher general health complaints were associated with higher perceived stress, lower mental toughness, and higher sleep complaints. Higher perceived stress was associated with lower mental toughness and with more sleep complaints. Higher mental toughness scores were associated with lower sleep complaints.

As regards light exercisers, age was not associated with general health, perceived stress, mental toughness, or sleep complaints. Higher general health complaints were associated with higher perceived stress and higher sleep complaints, but not with mental toughness. Higher perceived stress was associated with lower mental toughness, but not with sleep complaints. Mental toughness was unrelated to sleep complaints.

\subsection{General Health, Perceived Stress, Mental Toughness, and Sleep Complaints; Differences between Heavy and Light Exercisers}

Table 3 provides the descriptive and inferential statistical indices for perceived stress, mental toughness, and sleep complaints between heavy and light exercisers. 
Table 3. Inferential statistical indices of general health, perceived stress, mental toughness, and sleep complaints between heavy and light exercisers.

\begin{tabular}{|c|c|c|c|c|}
\hline & & & Statistics & \\
\hline & Heavy & Light & $t$-Tests & Effect Sizes \\
\hline \multirow[t]{2}{*}{$\mathrm{N}$} & 100 & 100 & & \\
\hline & $\mathrm{M}(\mathrm{SD})$ & $\mathrm{M}(\mathrm{SD})$ & & Cohen's d \\
\hline Perceived stress & $36.06(4.17)$ & $33.08(5.20)$ & $t(198)=4.47^{* * *}$ & $0.776[\mathrm{M}]$ \\
\hline Mental toughness & $32.51(5.57)$ & $30.09(6.16)$ & $t(198)=2.91^{* *}$ & $0.054[\mathrm{M}]$ \\
\hline Sleep complaints & $5.07(2.55)$ & $4.54(2.47)$ & $t(198)=1.49$ & $0.237[S]$ \\
\hline General health & & & F-tests (MANOVA) & Partial eta-squared \\
\hline Somatization & $6.09(3.50)$ & $5.14(2.67)$ & $\mathrm{F}(1,198)=4.64 *$ & $0.023[\mathrm{~S}]$ \\
\hline Anxiety & $6.10(3.19)$ & $4.92(2.75)$ & $F(1,198)=7.83^{* *}$ & $0.038[S]$ \\
\hline Social functioning & $5.66(3.56)$ & $6.93(2.24)$ & $F(1,198)=9.04 * *$ & $0.044[S]$ \\
\hline Depression & $3.97(3.66)$ & $2.22(2.67$ & $\mathrm{F}(1,198)=14.89^{* * *}$ & $0.070[\mathrm{M}]$ \\
\hline Total score & $21.82(12.59)$ & $19.21(8.05)$ & $\mathrm{F}(1,198)=3.05 *$ & $0.089[\mathrm{M}]$ \\
\hline
\end{tabular}

Notes: MANOVA = multivariate analysis of variance; ${ }^{*}=p<0.05 ;{ }^{* *}=p<0.01 ;{ }^{* * *}=p<0.001 ; \mathrm{S}=$ small effect size; $\mathrm{M}=$ medium effect size.

Compared with light exercisers, heavy exercisers reported higher perceived stress and higher mental toughness (significant $p$-values; always medium effect sizes). Sleep complaints did not differ.

Further, compared with light exercisers, heavy exercisers reported higher somatization, anxiety, depression, and overall scores (significant $p$-values; small effect sizes) and lower social functioning scores (significant $p$-value; small effect size).

\subsection{Predicting General Health}

To predict general health, a multiple regression was performed with the general health score as a dependent variable and perceived stress, mental toughness, sleep complaints, and exerciser status (heavy vs. light), age, gender, and the exercise status-sleep-disturbances interaction as predictors. Table 4 provides all statistical indices.

Table 4. Multiple linear regression with general health as outcome variable, and perceived stress, mental toughness, sleep disturbances, exerciser status, age, and gender as predictors.

\begin{tabular}{|c|c|c|c|c|c|c|c|c|c|}
\hline Dimension & Variables & Coefficient & Standard Error & Coefficient $\beta$ & $t$ & $p$ & $\mathbf{R}$ & $\mathbf{R}^{2}$ & $\begin{array}{l}\text { Durbin- } \\
\text { Watson }\end{array}$ \\
\hline \multirow{7}{*}{$\begin{array}{l}\text { General } \\
\text { Health }\end{array}$} & Intercept & 9.607 & 2.33 & - & 4.116 & 0.000 & 0.683 & 0.466 & 1.68 \\
\hline & PSQI & 2.601 & 0.229 & 0.617 & 11.310 & 0.000 & & & \\
\hline & Mental toughness & -0.221 & 0.114 & -0.134 & -2.175 & 0.03 & & & \\
\hline & Exercise status ${ }^{1}$ & -3.989 & 1.15 & -0.118 & -3.580 & 0.000 & & & \\
\hline & Age & 0.120 & 0.043 & 0.158 & 2.93 & 0.004 & & & \\
\hline & $\begin{array}{l}\text { Exercise status } \times \\
\text { sleep complaints } \\
\text { interaction }^{2}\end{array}$ & -0.932 & 0.460 & -0.110 & -2.030 & 0.044 & & & \\
\hline & & Excluded & ariables: Perceiv & stress; gender; & $<1.0 ; p s$ & $>0.30$ & & & \\
\hline
\end{tabular}

Notes: PSQI = Pittsburgh sleep quality index; higher scores reflect more impaired sleep; ${ }^{1}=$ heavy exercisers; ${ }^{2}=$ light exercisers. $^{.}$

More impaired sleep, lower mental toughness scores, heavy exercise status, older age, and a higher exercise-status-sleep-disturbance interaction predicted more impaired general health. Perceived stress and gender were excluded from the equation, as these dimensions did not reach statistical significance.

The exercise-status-sleep-disturbances interaction showed that heavy exercisers with more sleep disturbances also reported more psychological health issues. 


\section{Discussion}

The key findings of the present study were that compared with light exercisers, heavy exercisers reported more mental health issues, including higher perceived stress, but also higher mental toughness scores and less sleep disturbances. Higher sleep disturbances, lower mental toughness scores and heavy exerciser status predicted higher mental health issues. Further, the combination of being a heavy exerciser with high sleep disturbances predicted higher mental health issues (see Table 4). In our opinion, the present results expand upon the current literature in three important ways:

- First, among Iranian heavy exercisers, self-reported mental health issues along with higher perceived stress could be observed.

- Second, such health issues were highly associated with poor sleep.

- Third, higher mental toughness indices were associated with less mental health issues, but more so among heavy exercisers; in contrast, higher mental toughness scores were associated with lower perceived stress indices among light exercisers.

Overall, the data suggest that among Iranian adults identified as heavy exercisers, mental health issues could be observed. As a consequence, exercisers, coaches, and representatives of sports organizations should be sensitized to the rule of thumb, that "more is not always better".

Two hypotheses and two research questions were formulated, and each of these is considered now in turn.

In the first hypothesis, we assumed that compared with light exercisers, heavy exercisers reported less sleep disturbances, and data did confirm this. Thus, the present data confirmed previous results [33,132-140]. However, we expanded upon previous results in that such associations were observed among heavy adult exercisers in Iran. Next, we also note that other studies also showed exactly the opposite: compared with non-athletes, professional athletes self-reported more sleep disturbances [163-166].

In the second hypothesis, we predicted that compared with light exercisers, heavy exercisers would report lower stress scores; though, data did confirm exactly the opposite. Given this, the present findings do not match what has been observed elsewhere [60,84-90]. Results are discussed in more details below, when dealing with the two research questions.

The first research question we asked was if and to what extent heavy exercisers would report more favorable or more unfavorable general health scores and mental toughness scores compared with light exercisers. The answer was not straightforward; while heavy exercisers reported higher mental toughness scores, they also reported more mental health issues. While the former result could be expected from what we know from previous studies [34,101-118], the latter result appears to confirm the raising research that excessive exercising could also be associated with mental health issues [91-98]. Thus, we claim that the present data expand upon the sparse but increasing literature on the unfavorable association between excessive exercising and mental health issues, in that such a pattern was also observed among heavily exercising Iranian adults.

The associations between higher mental toughness scores and higher mental health issues among heavy exercisers demand more attention. First, we note that the correlation coefficient was negative $(r=-0.29$; see Table 2$)$; this would imply that higher mental toughness and lower mental health issues were associated. However, as noted above, heavy exercisers did report both higher mental toughness and higher mental health issues, which appears to be contradictory. To solve this apparent contradiction, we note that athletes with high mental toughness scores might be at risk of overtraining [125] and of displaying also negative personality traits, such as the so-called dark trait [126-128]. Similarly, heavy exercisers also reported higher symptoms of depression, mental toughness, over-adherence to physical activity intensity, playing through pain, and injury severity [129]. Given this, we claim that such unfavorable associations could also appear in the present sample of heavy exercisers. Note that results are discussed in more details below when dealing with the two research questions. 
In the second research question, we asked, with factors could predict higher mental health issues, and the answer was: poor sleep, lower mental toughness scores, heavy exerciser status, higher age, and an unfavorable exercise-status-sleep-disturbances interaction (see Table 4). Thus, the regression equation confirmed that the combination of several factors predicted higher mental health issues, and again, heavy exerciser status was among these predictors, while perceived stress or gender did not reach statistical significance.

Heavy exerciser status and higher mental health issues were associated, and this pattern of results demands more attention. To this end, we give a closer examination to the exercise-status-sleep-disturbance interaction.

In regard to the exercise-status-sleep-disturbance interaction, we noted that the combination of heavy exercise status and higher sleep disturbances predicted higher general health issues. This pattern of results appears particularly intriguing, as it does not follow the mainstream of interventional $[130,131]$ and associative studies [33,132-137], which suggested that higher physical activity levels favorably impacted on sleep quality. Thus, while we asked if heavy exercisers reported less sleep disturbances, compared with light exercisers, the answer was no (see Table 3); however, the combination of being a heavy exerciser and reporting sleep disturbances was important, as this combination impacted negatively on mental health.

Further, the following admittedly speculative assumptions are made:

First, it is conceivable that the extensive exercising duration, frequency, and intensity put the exerciser into a dilemma as regards balancing the budget of time and resources against the time and resources needed for working and family life. To illustrate, among 292 undergraduate students, extreme exercise schedules interfered with their social, occupational, and family lives [167]. Similarly, among professional body builders, excessive exercising increased the risk of issues with social and occupational functions, along with subjective distress, and adverse health consequences [168].

Second, it is conceivable that excessive exercising behavior might be associated with dimensions of (pre-existing) psychopathology, such as maladaptive perfectionism [169] or dysfunctional coping with stress [170].

Third, blending the first and second claim, it is conceivable that excessive exercising was not the trigger of stress, but a dysfunctional answer to stress.

Fourth, physiological dimensions are conceivable; more specifically, at the mitochondrial level, "there is too much of a good thing"; excessive training impaired mitochondrial activity and decreased glucose tolerance, at least among adult healthy volunteers [171,172]. In contrast, among male adults with symptoms of burnout, an exercise-related increased mitochondrial activity over time was associated with a more favorable recovery [53].

To conclude, several hypothetical pathways are conceivable to describe why heavy exercising might have been associated with higher mental health issues.

Despite the novelty of the results, the following limitations warrant against their overgeneralization. First, the cross-sectional design precluded any causality. However, to run multiple regressions, predictors and dependent variables must be defined a priori. In this view, we assumed that poor sleep, low mental toughness scores, and heavy exerciser status predicted general heath; however, it is also conceivable that poor mental health instigated the increase of exercise frequency, intensity, and duration as a strategy to cope with psychological health issues. Meanwhile, there is sufficient evidence that moderate to vigorous physical activity patterns favorably impact on psychological well-being [173]. Furthermore, perceived stress negatively impacted on physical activity and exercise [174]. Similarly, a bidirectional interactional effect between physical activity patterns and psychological well-being might be the most appropriate model. Second, sample selections were such to clearly identify participants' physical activity duration and frequency based on both participants' self-reports and their supervisors' information. However, a detailed assessment of participants' physical activity patterns would have allowed to introduce this dimension as a further factor. Third, unlike other case-control studies, we did not run an a priori sample size calculation. While the lack of sample size calculations bears 
the risk to miss small but important mean differences, which could have yielded further important patterns of results, on the flip side, we relied on effect sizes, which by nature are not sensitive to sample sizes. Fourth, higher physical activity traits are associated with lower [170] or higher self-esteem [175,176], along with a higher risk of eating-disordered behavior [170]; it is therefore conceivable that self-esteem, eating-disordered behavior, and further latent and un-assessed psychological dimensions might have biased two or more variables in the same or opposite directions. Fifth, by definition, a longitudinal design would have allowed to gain more insight into causal associations between excessive exercising and mental health issues.

\section{Conclusions}

Compared with light exercising, heavy exercising was associated with mental health issues and higher perceived stress, but also with higher mental toughness scores and lower sleep complaints. Overall, it appeared that "more (heavy exercising) is not better (mental health)"; as such, heavy exercisers, but also coaches, parents of promising junior athletes, and representatives of sports associations should consider paying special attention to mental health issues.

Author Contributions: Conceptualization, S.G. (Sanobar Golshani), A.N., S.S.H., N.G., F.S., S.G. (Sanam Golshani), M.B., K.F., K.M.D., A.B.B., J.S., S.B., and D.S.-B.; methodology, S.G. (Sanobar Golshani), A.N., S.S.H., N.G., F.S., S.G. (Sanam Golshani), M.B., K.F., K.M.D., A.B.B., J.S., S.B., and D.S.-B. validation, S.G. (Sanobar Golshani), A.N., S.S.H., N.G., F.S., S.G. (Sanam Golshani), M.B., K.F., K.M.D., A.B.B., formal analysis, M.B., K.F., K.M.D., A.B.B., S.B., and D.S.-B.; investigation, S.G. (Sanobar Golshani), A.N., S.S.H., N.G., F.S., S.G. (Sanam Golshani), M.B., K.F., and K.M.D.; resources, S.G. (Sanobar Golshani), A.N., S.S.H., N.G., J.S., S.G. (Sanam Golshani), F.S., K.F., and M.B.; data curation, S.G. (Sanobar Golshani), A.N., S.S.H., N.G., F.S., S.G. (Sanam Golshani), M.B., K.F., and K.M.D.; writing-original draft preparation, M.B., K.F., K.M.D., A.B.B., J.S., S.B., and D.S.-B.; writing-review and editing, S.G. (Sanobar Golshani), A.N., S.S.H., N.G., F.S., S.G. (Sanam Golshani), M.B., K.F., K.M.D., A.B.B., J.S., S.B., and D.S.-B. All authors have read and agreed to the published version of the manuscript.

Funding: The whole study was performed without external funding.

Institutional Review Board Statement: The ethical committee of the Kermanshah University of Medical Science (KUMS; Kermanshah, Iran; Ethics ID: IR. KUMS. REC. 1398. 583) approved the study.

Informed Consent Statement: All participants signed the written informed consent.

Data Availability Statement: Data are made available upon request to experts in the field and upon through explanations of why and how data are used.

Acknowledgments: We thank Balz Furlano (University of Basel, Basel, Switzerland) for formatting the files, and we thank all participants and their relatives. The present results are a part of the thesis of Fatemeh Shahmari to achieve the title of Medical Doctor. Further, we thank the Psychiatric Clinics of the University of Basel (UPK, Basel, Switzerland) for their financial support to publish the paper as an open-access paper.

Conflicts of Interest: All authors have no conflict of interest to disclose.

\section{References}

1. Ekelund, U.; Dalene, K.E.; Tarp, J.; Lee, I.-M. Physical activity and mortality: What is the dose response and how big is the effect? Br. J. Sports Med. 2020, 54, 1125-1126. [CrossRef]

2. $\quad$ Ekelund, U.; Steene-Johannessen, J.; Brown, W.J.; Fagerland, M.W.; Owen, N.; Powell, K.E.; Bauman, A.; Lee, I.-M.; Lancet Sedentary Behaviour Working Group. Does physical activity attenuate, or even eliminate, the detrimental association of sitting time with mortality? A harmonised meta-analysis of data from more than 1 million men and women. Lancet 2016, 388, 1302-1310. [CrossRef]

3. Ekelund, U.; Tarp, J.; Steene-Johannessen, J.; Hansen, B.H.; Jefferis, B.; Fagerland, M.W.; Whincup, P.; Diaz, K.M.; Hooker, S.P.; Chernofsky, A.; et al. Dose-response associations between accelerometry measured physical activity and sedentary time and all cause mortality: Systematic review and harmonised meta-analysis. BMJ 2019, 366, 14570. [CrossRef] [PubMed] 
4. Stamatakis, E.; Gale, J.; Bauman, A.; Ekelund, U.; Hamer, M.; Ding, D. Sitting Time, Physical Activity, and Risk of Mortality in Adults. J. Am. Coll. Cardiol. 2019, 73, 2062-2072. [CrossRef] [PubMed]

5. Patterson, R.; McNamara, E.; Tainio, M.; De Sá, T.H.; Smith, A.D.; Sharp, S.J.; Edwards, P.; Woodcock, J.; Brage, S.; Wijndaele, K. Sedentary behaviour and risk of all-cause, cardiovascular and cancer mortality, and incident type 2 diabetes: A systematic review and dose response meta-analysis. Eur. J. Epidemiol. 2018, 33, 811-829. [CrossRef]

6. Guthold, R.; Stevens, G.A.; Riley, L.M.; Bull, F.C. Global trends in insufficient physical activity among adolescents: A pooled analysis of 298 population-based surveys with 1.6 million participants. Lancet Child. Adolesc. Health 2019, 4, 23-35. [CrossRef]

7. Fennell, C.; Lepp, A.; Barkley, J. Smartphone Use Predicts Being an "Active Couch Potato" in Sufficiently Active Adults. Am. J. Lifestyle Med. 2019. [CrossRef]

8. An, K.-Y. Physical activity level in Korean adults: The Korea National Health and Nutrition Examination Survey 2017. Epidemiol. Health 2019, 41, e2019047. [CrossRef]

9. Park, S.-M.; Kim, H.-J.; Jeong, H.; Kim, H.; Chang, B.-S.; Lee, C.-K.; Yeom, J.S. Longer sitting time and low physical activity are closely associated with chronic low back pain in population over 50 years of age: A cross-sectional study using the sixth Korea National Health and Nutrition Examination Survey. Spine J. 2018, 18, 2051-2058. [CrossRef]

10. Lee, Y.; Son, J.S.; Eum, Y.H.; Kang, O.L. Association of Sedentary Time and Physical Activity with the 10-Year Risk of Cardiovascular Disease: Korea National Health and Nutrition Examination Survey 2014-2017. Korean J. Fam. Med. 2020, 41, 374-380. [CrossRef]

11. Park, J.H.; Moon, J.H.; Kim, H.J.; Kong, M.H.; Oh, Y.H. Sedentary Lifestyle: Overview of Updated Evidence of Potential Health Risks. Korean J. Fam. Med. 2020, 41, 365-373. [CrossRef] [PubMed]

12. Stubbs, B.; Vancampfort, D.; Hallgren, M.; Firth, J.; Veronese, N.; Solmi, M.; Brand, S.; Cordes, J.; Malchow, B.; Gerber, M.; et al. EPA guidance on physical activity as a treatment for severe mental illness: A meta-review of the evidence and Position Statement from the European Psychiatric Association (EPA), supported by the International Organization of Physical Therapists in Mental Health (IOPTMH). Eur. Psychiatry 2018, 54, 124-144. [CrossRef] [PubMed]

13. Ashdown-Franks, G.; Koyanagi, A.; Vancampfort, D.; Smith, L.; Firth, J.; Schuch, F.; Veronese, N.; Stubbs, B. Sedentary behavior and perceived stress among adults aged $\geq 50$ years in six low- and middle-income countries. Maturitas 2018, 116, $100-107$. [CrossRef] [PubMed]

14. An, K.O.; Jang, J.Y.; Kim, J. Sedentary Behavior and Sleep Duration Are Associated with Both Stress Symptoms and Suicidal Thoughts in Korean Adults. Tohoku J. Exp. Med. 2015, 237, 279-286. [CrossRef] [PubMed]

15. Falck, R.S.; Davis, J.C.; Liu-Ambrose, T. What is the association between sedentary behaviour and cognitive function? A systematic review. Br. J. Sports Med. 2017, 51, 800-811. [CrossRef]

16. Yang, Y.; Shin, J.C.; Li, D.; An, R. Sedentary Behavior and Sleep Problems: A Systematic Review and Meta-Analysis. Int. J. Behav. Med. 2017, 24, 481-492. [CrossRef]

17. Esteghamati, A.; Khalilzadeh, O.; Rashidi, A.; Kamgar, M.; Meysamie, A.; Abbasi, M. Physical Activity in Iran: Results of the Third National Surveillance of Risk Factors of Non-Communicable Diseases (SuRFNCD-2007). J. Phys. Act. Health 2011, 8, 27-35. [CrossRef]

18. Mohebi, F.; Mohajer, B.; Yoosefi, M.; Sheidaei, A.; Zokaei, H.; Damerchilu, B.; Mehregan, A.; Shahbal, N.; Rezaee, K.; Khezrian, M.; et al. Physical activity profile of the Iranian population: STEPS survey, 2016. BMC Public Health 2019, 19, 1-17. [CrossRef]

19. Grande, I.; Berk, M.; Birmaher, B.; Vieta, E. Bipolar disorder. Lancet 2016, 387, 1561-1572. [CrossRef]

20. Buss, D.M. Evolutionary Psychology: The New Science of the Mind, 6th ed.; Routledge: New York, NY, USA, 2019.

21. Miller, G. The Mating Mind: How Sexual Choice Shaped the Evolution of Human Nature; Heineman: London, UK, 2000.

22. Brüne, M. Textbook of Evolutionary Psychiatry and Psychosomatic Medicine: The Origins of Psychopathology; Oxford University Press: Oxford, UK, 2015.

23. Motallebi, L.; Noorbakhsh, M. Study the effect of participation in physical activity on mental health. Br. J. Sports Med. 2010, 44, i60. [CrossRef]

24. Donnelly, J.E.; Hillman, C.; Castelli, D.; Etnier, J.L.; Lee, S.; Tomporowski, P.; Lambourne, K.; Szabo-Reed, A. Physical Activity, Fitness, Cognitive Function, and Academic Achievement in Children: A Systematic Review. Med. Sci. Sports Exerc. 2016, 48, 1197-1222. [CrossRef]

25. Gabbard, C.; Barton, J. Effects of Physical Activity on Mathematical Computation among Young Children. J. Psychol. 1979, 103, 287-288.

26. Gerber, M.; Endes, K.; Herrmann, C.; Colledge, F.; Brand, S.; Donath, L.; Faude, O.; Pühse, U.; Hanssen, H.; Zahner, L. Fitness, Stress, and Body Composition in Primary Schoolchildren. Med. Sci. Sports Exerc. 2017, 49, 581-587. [CrossRef]

27. Liu, M.; Wu, L.; Ming, Q. How Does Physical Activity Intervention Improve Self-Esteem and Self-Concept in Children and Adolescents? Evidence from a Meta-Analysis. PLoS ONE 2015, 10, e0134804. [CrossRef]

28. Sibley, B.A.; Etnier, J.L. The Relationship between Physical Activity and Cognition in Children: A Meta-Analysis. Pediatr. Exerc. Sci. 2003, 15, 243-256. [CrossRef]

29. Mählmann, L.; Gerber, M.; Furlano, R.I.; Legeret, C.; Kalak, N.; Holsboer-Trachsler, E.; Brand, S. Psychological wellbeing and physical activity in children and adolescents with inflammatory bowel disease compared to healthy controls. BMC Gastroenterol. 2017, 17, 160. [CrossRef] [PubMed] 
30. Mählmann, L.; Gerber, M.; Furlano, R.I.; Legeret, C.; Kalak, N.; Holsboer-Trachsler, E.; Brand, S. Aerobic exercise training in children and adolescents with inflammatory bowel disease: Influence on psychological functioning, sleep and physical performance-An exploratory trial. Ment. Health Phys. Act. 2017, 13, 30-39. [CrossRef]

31. Babiss, L.A.; Gangwisch, J.E. Sports Participation as a Protective Factor Against Depression and Suicidal Ideation in Adolescents as Mediated by Self-Esteem and Social Support. J. Dev. Behav. Pediatr. 2009, 30, 376-384. [CrossRef] [PubMed]

32. Bailey, A.P.; Hetrick, S.; Rosenbaum, S.; Purcell, R.; Parker, A.G. Treating depression with physical activity in adolescents and young adults: A systematic review and meta-analysis of randomised controlled trials. Psychol. Med. 2018, 48, 1068-1083. [CrossRef]

33. Brand, S.; Gerber, M.; Beck, J.; Hatzinger, M.; Pühse, U.; Holsboer-Trachsler, E. High Exercise Levels Are Related to Favorable Sleep Patterns and Psychological Functioning in Adolescents: A Comparison of Athletes and Controls. J. Adolesc. Health Off. Publ. Soc. Adolesc. Med. 2010, 46, 133-141. [CrossRef] [PubMed]

34. Brand, S.; Kalak, N.; Gerber, M.; Clough, P.J.; Lemola, S.; Bahmani, D.S.; Pühse, U.; Holsboer-Trachsler, E. During early to mid adolescence, moderate to vigorous physical activity is associated with restoring sleep, psychological functioning, mental toughness and male gender. J. Sports Sci. 2017, 35, 426-434. [CrossRef]

35. Esteban-Cornejo, I.; Tejero-Gonzalez, C.M.; Sallis, J.F.; Veiga, O.L. Physical activity and cognition in adolescents: A systematic review. J. Sci. Med. Sport 2015, 18, 534-539. [CrossRef]

36. Arrieta, H.; Rezola-Pardo, C.; Echeverría, I.; Iturburu, M.; Gil, S.M.; Yanguas, J.J.; Irazusta, J.; Rodriguez-Larrad, A. Physical activity and fitness are associated with verbal memory, quality of life and depression among nursing home residents: Preliminary data of a randomized controlled trial. BMC Geriatr. 2018, 18, 80. [CrossRef]

37. Bherer, L.; Erickson, K.I.; Liu-Ambrose, T. A Review of the Effects of Physical Activity and Exercise on Cognitive and Brain Functions in Older Adults. J. Aging Res. 2013, 2013, 657508. [CrossRef]

38. Chan, B.C.L.; Luciano, M.; Lee, B. Interaction of Physical Activity and Personality in the Subjective Wellbeing of Older Adults in Hong Kong and the United Kingdom. Behav. Sci. 2018, 8, 71. [CrossRef] [PubMed]

39. De Labra, C.; Guimaraes-Pinheiro, C.; Maseda, A.; Lorenzo, T.; Millán-Calenti, J.C. Effects of physical exercise interventions in frail older adults: A systematic review of randomized controlled trials. BMC Geriatr. 2015, 15, 1-16. [CrossRef] [PubMed]

40. Devereux-Fitzgerald, A.; Powell, R.; Dewhurst, A.; French, D.P. The acceptability of physical activity interventions to older adults: A systematic review and meta-synthesis. Soc. Sci. Med. 2016, 158, 14-23. [CrossRef] [PubMed]

41. Ekkekakis, P.; Hall, E.E.; Petruzzello, S. The Relationship Between Exercise Intensity and Affective Responses Demystified: To Crack the 40-Year-Old Nut, Replace the 40-Year-Old Nutcracker! Ann. Behav. Med. 2008, 35, 136-149. [CrossRef]

42. Levin, O.; Netz, Y.; Ziv, G. The beneficial effects of different types of exercise interventions on motor and cognitive functions in older age: A systematic review. Eur. Rev. Aging Phys. Act. 2017, 14, 20. [CrossRef]

43. Lim, K.-C.; Kayser-Jones, J.S.; Waters, C.; Yoo, G. Aging, Health, and Physical Activity in Korean Americans. Geriatr. Nurs. 2007, 28, 112-119. [CrossRef] [PubMed]

44. Ludyga, S.; Gerber, M.; Brand, S.; Holsboer-Trachsler, E.; Pühse, U. Acute effects of moderate aerobic exercise on specific aspects of executive function in different age and fitness groups: A meta-analysis. Psychophysiology 2016, 53, 1611-1626. [CrossRef]

45. Ludyga, S.; Schilling, R.; Colledge, F.; Brand, S.; Pühse, U.; Gerber, M. Association between cardiorespiratory fitness and social cognition in healthy adults. Scand. J. Med. Sci. Sports 2020, 30, 1722-1728. [CrossRef] [PubMed]

46. Reid, K.J.; Baron, K.G.; Lu, B.; Naylor, E.; Wolfe, L.; Zee, P.C. Aerobic exercise improves self-reported sleep and quality of life in older adults with insomnia. Sleep Med. 2010, 11, 934-940. [CrossRef] [PubMed]

47. Smith, L.; Gardner, B.; Fisher, A.; Hamer, M. Patterns and correlates of physical activity behaviour over 10 years in older adults: Prospective analyses from the English Longitudinal Study of Ageing. BMJ Open 2015, 5, e007423. [CrossRef] [PubMed]

48. Have, M.T.; de Graaf, R.; Monshouwer, K. Physical exercise in adults and mental health status findings from the Netherlands mental health survey and incidence study (NEMESIS). J. Psychosom. Res. 2011, 71, 342-348. [CrossRef]

49. Vancampfort, D.; Stubbs, B.; Hallgren, M.; Veronese, N.; Mugisha, J.; Probst, M.; Koyanagi, A. Correlates of physical activity among community-dwelling individuals aged 65 years or older with anxiety in six low- and middle-income countries. Int. Psychogeriatr. 2018, 30, 705-714. [CrossRef]

50. Winzer, R.; Sorjonen, K.; Lindberg, L. What Predicts Stable Mental Health in the 18-29 Age Group Compared to Older Age Groups? Results from the Stockholm Public Health Cohort 2002-2014. Int. J. Environ. Res. Public Health 2018, 15, 2859. [CrossRef]

51. Archer, T.; Josefsson, T.; Lindwall, M. Effects of physical exercise on depressive symptoms and biomarkers in depression. CNS Neurol. Disord. Drug Targets 2015, 13, 1640-1653. [CrossRef]

52. Booth, F.W.; Roberts, C.K.; Laye, M.J. Lack of Exercise Is a Major Cause of Chronic Diseases. Compr. Physiol. 2012, 2, $1143-1211$. [CrossRef]

53. Brand, S.; Ebner, K.; Mikoteit, T.; Lejri, I.; Gerber, M.; Beck, J.; Holsboer-Trachsler, E.; Eckert, A. Influence of Regular Physical Activity on Mitochondrial Activity and Symptoms of Burnout-An Interventional Pilot Study. J. Clin. Med. 2020, 9, 667. [CrossRef]

54. Brondino, N.; Rocchetti, M.; Fusar-Poli, L.; Codrons, E.; Correale, L.; Vandoni, M.; Barbui, C.; Politi, P. A systematic review of cognitive effects of exercise in depression. Acta Psychiatr. Scand. 2017, 135, 285-295. [CrossRef] [PubMed]

55. Dillon, C.B.; McMahon, E.; O'Regan, G.; Perry, I. Associations between physical behaviour patterns and levels of depressive symptoms, anxiety and well-being in middle-aged adults: A cross-sectional study using isotemporal substitution models. BMJ Open 2018, 8, e018978. [CrossRef] 
56. Dunn, A.L.; Trivedi, M.H.; Kampert, J.B.; Clark, C.G.; Chambliss, H.O. Exercise treatment for depression: Efficacy and dose response. Am. J. Prev. Med. 2005, 28, 1-8. [CrossRef]

57. Farah, W.H.; Alsawas, M.; Mainou, M.; Alahdab, F.; Farah, M.; Ahmed, A.T.; A Mohamed, E.; Almasri, J.; Gionfriddo, M.R.; Castaneda-Guarderas, A.; et al. Non-pharmacological treatment of depression: A systematic review and evidence map. Evid.-Based Med. 2016, 21, 214-221. [CrossRef]

58. Gudmundsson, P.; Lindwall, M.; Gustafson, D.R.; Östling, S.; Hällström, T.; Waern, M.; Skoog, I. Longitudinal associations between physical activity and depression scores in Swedish women followed 32 years. Acta Psychiatr. Scand. 2015, 132, 451-458. [CrossRef]

59. Josefsson, T.; Lindwall, M.; Archer, T. Physical exercise intervention in depressive disorders: Meta-analysis and systematic review. Scand. J. Med. Sci. Sports 2013, 24, 259-272. [CrossRef]

60. Lindegård, A.; Jonsdottir, I.H.; Börjesson, M.; Lindwall, M.; Gerber, M. Changes in mental health in compliers and non-compliers with physical activity recommendations in patients with stress-related exhaustion. BMC Psychiatry 2015, 15, 1-10. [CrossRef]

61. Lindwall, M.; Gerber, M.; Jonsdottir, I.H.; Börjesson, M.; Ahlborg, G. The relationships of change in physical activity with change in depression, anxiety, and burnout: A longitudinal study of Swedish healthcare workers. Health Psychol. 2014, 33, 1309-1318. [CrossRef] [PubMed]

62. Oberste, M.; Medele, M.; Javelle, F.; Wunram, H.L.; Walter, D.; Bloch, W.; Bender, S.; Fricke, O.; Joisten, N.; Walzik, D.; et al. Physical Activity for the Treatment of Adolescent Depression: A Systematic Review and Meta-Analysis. Front. Physiol. $2020,11$. [CrossRef] [PubMed]

63. Pedersen, B.K.; Saltin, B. Exercise as medicine-Evidence for prescribing exercise as therapy in 26 different chronic diseases. Scand. J. Med. Sci. Sports 2015, 25, 1-72. [CrossRef] [PubMed]

64. Sartori, C.; Vieira, A.S.; Ferrari, E.; Langone, F.; Tongiorgi, E.; Parada, C. The antidepressive effect of the physical exercise correlates with increased levels of mature BDNF, and proBDNF proteolytic cleavage-related genes, p11 and tPA. Neuroscience 2011, 180, 9-18. [CrossRef] [PubMed]

65. Scholz, U.; Knoll, N.; Sniehotta, F.F.; Schwarzer, R. Physical activity and depressive symptoms in cardiac rehabilitation: Long-term effects of a self-management intervention. Soc. Sci. Med. 2006, 62, 3109-3120. [CrossRef]

66. Schuch, F.B.; Morres, I.D.; Ekkekakis, P.; Rosenbaum, S.; Stubbs, B. A critical review of exercise as a treatment for clinically depressed adults: Time to get pragmatic. Acta Neuropsychiatr. 2017, 29, 65-71. [CrossRef] [PubMed]

67. Stubbs, B.; Rosenbaum, S.; Vancampfort, D.; Ward, P.; Schuch, F. Exercise improves cardiorespiratory fitness in people with depression: A meta-analysis of randomized control trials. J. Affect. Disord. 2016, 190, 249-253. [CrossRef] [PubMed]

68. Wu, P.-L.; Lee, M.; Huang, T.-T. Effectiveness of physical activity on patients with depression and Parkinson's disease: A systematic review. PLoS ONE 2017, 12, e0181515. [CrossRef]

69. Asano, M.; Duquette, P.; Andersen, R.; Lapierre, Y.; Mayo, N.E. Exercise barriers and preferences among women and men with multiple sclerosis. Disabil. Rehabil. 2013, 35, 353-361. [CrossRef] [PubMed]

70. Casey, B.; Coote, S.; Hayes, S.; Gallagher, S. Changing Physical Activity Behavior in People With Multiple Sclerosis: A Systematic Review and Meta-Analysis. Arch. Phys. Med. Rehabil. 2018, 99, 2059-2075. [CrossRef]

71. Coote, S.; Uszynski, M.; Herring, M.P.; Hayes, S.; Scarrott, C.; Newell, J.; Gallagher, S.; Larkin, A.; Motl, R.W. Effect of exercising at minimum recommendations of the multiple sclerosis exercise guideline combined with structured education or attention control education-Secondary results of the step it up randomised controlled trial. BMC Neurol. 2017, 17, 1-14. [CrossRef]

72. Cowan, R.E. Exercise Is Medicine Initiative: Physical Activity as a Vital Sign and Prescription in Adult Rehabilitation Practice. Arch. Phys. Med. Rehabil. 2016, 97, S232-S237. [CrossRef]

73. Giesser, B.S. Exercise in the management of persons with multiple sclerosis. Ther. Adv. Neurol. Disord. 2015, 8, 123-130. [CrossRef]

74. Kalb, R.; Brown, T.R.; Coote, S.; Costello, K.; Dalgas, U.; Garmon, E.; Giesser, B.; Halper, J.; Karpatkin, H.; Keller, J.; et al. Exercise and lifestyle physical activity recommendations for people with multiple sclerosis throughout the disease course. Mult. Scler. J. 2020, 26, 1459-1469. [CrossRef] [PubMed]

75. Latimer-Cheung, A.E.; Ginis, K.M.; Hicks, A.L.; Motl, R.W.; Pilutti, L.A.; Duggan, M.; Wheeler, G.; Persad, R.; Smith, K.M. Development of Evidence-Informed Physical Activity Guidelines for Adults with Multiple Sclerosis. Arch. Phys. Med. Rehabil. 2013, 94, 1829-1836. [CrossRef]

76. Motl, R.W.; Pilutti, L.A. Is physical exercise a multiple sclerosis disease modifying treatment? Expert Rev. Neurother. 2016, 16, 951-960. [CrossRef] [PubMed]

77. Motl, R.W.; Sandroff, B.; Kwakkel, G.; Dalgas, U.; Feinstein, A.; Heesen, C.; Feys, P.; Thompson, A. Exercise in patients with multiple sclerosis. Lancet Neurol. 2017, 16, 848-856. [CrossRef]

78. Razazian, N.; Kazeminia, M.; Moayedi, H.; Daneshkhah, A.; Shohaimi, S.; Mohammadi, M.; Jalali, R.; Salari, N. The impact of physical exercise on the fatigue symptoms in patients with multiple sclerosis: A systematic review and meta-analysis. $B M C$ Neurol. 2020, 20, 1-11. [CrossRef] [PubMed]

79. Bahmani, D.S.; Gonzenbach, R.; Kesselring, J.; Bansi, J.; Motl, R.W.; Cordier, D.; Rothen, O.; Niedermoser, D.; Gerber, M.; Brand, S. Among Persons with Multiple Sclerosis (MS), Objective Sleep, Psychological Functioning, and Higher Physical Activity Scores Remained Stable Over 2 Years—Results from a Small Study Under Naturalistic Conditions. Front. Psychiatry 2020, 11, 586244. [CrossRef] 
80. Bahmani, D.S.; Gonzenbach, R.; Motl, R.W.; Bansi, J.; Rothen, O.; Niedermoser, D.; Gerber, M.; Brand, S. Better Objective Sleep Was Associated with Better Subjective Sleep and Physical Activity; Results from an Exploratory Study under Naturalistic Conditions among Persons with Multiple Sclerosis. Int. J. Environ. Res. Public Health 2020, 17, 3522. [CrossRef]

81. Bahmani, D.S.; Kesselring, J.; Papadimitriou, M.; Bansi, J.; Pühse, U.; Gerber, M.; Shaygannejad, V.; Holsboer-Trachsler, E.; Brand, S. In Patients with Multiple Sclerosis, Both Objective and Subjective Sleep, Depression, Fatigue, and Paresthesia Improved After 3 Weeks of Regular Exercise. Front. Psychiatry 2019, 10, 265. [CrossRef]

82. Bahmani, D.S.; Razazian, N.; Farnia, V.; Alikhani, M.; Tatari, F.; Brand, S. Compared to an active control condition, in persons with multiple sclerosis two different types of exercise training improved sleep and depression, but not fatigue, paresthesia, and intolerance of uncertainty. Mult. Scler. Relat. Disord. 2019, 36, 101356. [CrossRef]

83. Bahmani, D.S.; Razazian, N.; Motl, R.W.; Farnia, V.; Alikhani, M.; Pühse, U.; Gerber, M.; Brand, S. Physical activity interventions can improve emotion regulation and dimensions of empathy in persons with multiple sclerosis: An exploratory study. Mult. Scler. Relat. Disord. 2020, 37, 101380. [CrossRef]

84. Alirezaei, P.; Ahmadpanah, M.; Rezanejad, A.; Soltanian, A.; Bahmani, D.S.; Brand, S. Compared to Controls, Individuals with Lichen Planopilaris Have More Depression, a Lower Self-Esteem, and a Lower Quality of Life. Neuropsychobiology 2019, 78, 95-103. [CrossRef] [PubMed]

85. Gerber, M.; Brand, S.; Herrmann, C.; Colledge, F.; Holsboer-Trachsler, E.; Pühse, U. Increased objectively assessed vigorousintensity exercise is associated with reduced stress, increased mental health and good objective and subjective sleep in young adults. Physiol. Behav. 2014, 135, 17-24. [CrossRef] [PubMed]

86. Gerber, M.; Endes, K.; Herrmann, C.; Colledge, F.; Brand, S.; Donath, L.; Faude, O.; Pühse, U.; Hanssen, H.; Zahner, L. Does Physical Fitness Buffer the Relationship between Psychosocial Stress, Retinal Vessel Diameters, and Blood Pressure among Primary Schoolchildren? BioMed Res. Int. 2016, 2016, 6340431. [CrossRef]

87. Gerber, M.; Schilling, R.; Colledge, F.; Ludyga, S.; Pühse, U.; Brand, S. More than a simple pastime? The potential of physical activity to moderate the relationship between occupational stress and burnout symptoms. Int. J. Stress Manag. 2020, $27,53-64$. [CrossRef]

88. Sigfusdottir, I.D.; Asgeirsdottir, B.B.; Sigurdsson, J.F.; Gudjonsson, G.H. Physical activity buffers the effects of family conflict on depressed mood: A study on adolescent girls and boys. J. Adolesc. 2011, 34, 895-902. [CrossRef] [PubMed]

89. Wyss, T.; Boesch, M.; Roos, L.; Tschopp, C.; Frei, K.M.; Annen, H.; La Marca, R. Aerobic Fitness Level Affects Cardiovascular and Salivary Alpha Amylase Responses to Acute Psychosocial Stress. Sports Med.-Open 2016, 2, 33. [CrossRef]

90. Salmon, P. Effects of physical exercise on anxiety, depression, and sensitivity to stress: A unifying theory. Clin. Psychol. Rev. 2001, 21,33-61. [CrossRef]

91. Colledge, F.; Cody, R.; Buchner, U.G.; Schmidt, A.; Pühse, U.; Gerber, M.; Wiesbeck, G.; Lang, U.E.; Walter, M. Excessive Exercise-A Meta-Review. Front. Psychiatry 2020, 11, 521572. [CrossRef] [PubMed]

92. Colledge, F.; Sattler, I.; Schilling, H.; Gerber, M.; Pühse, U.; Walter, M. Mental disorders in individuals at risk for exercise addiction-A systematic review. Addict. Behav. Rep. 2020, 12, 100314. [CrossRef]

93. Back, J.; Josefsson, T.; Ivarsson, A.; Gustafsson, H. Psychological risk factors for exercise dependence. Int. J. Sport Exerc. Psychol. 2021, 19, 461-472. [CrossRef]

94. Corazza, O.; Simonato, P.; Demetrovics, Z.; Mooney, R.; van de Ven, K.; Roman-Urrestarazu, A.; Rácmolnár, L.; De Luca, I.; Cinosi, E.; Santacroce, R.; et al. The emergence of Exercise Addiction, Body Dysmorphic Disorder, and other image-related psychopathological correlates in fitness settings: A cross sectional study. PLoS ONE 2019, 14, e0213060. [CrossRef] [PubMed]

95. Hausenblas, H.A.; Schreiber, K.; Smoliga, J. Addiction to exercise. BMJ 2017, 357, j1745. [CrossRef]

96. Landolfi, E. Exercise Addiction. Sports Med. 2013, 43, 111-119. [CrossRef]

97. Macfarlane, L.; Owens, G.; Cruz, B.D.P. Identifying the features of an exercise addiction: A Delphi study. J. Behav. Addict. 2016, 5, 474-484. [CrossRef]

98. Weinstein, A.; Weinstein, Y. Exercise Addiction- Diagnosis, Bio-Psychological Mechanisms and Treatment Issues. Curr. Pharm. Des. 2014, 20, 4062-4069. [CrossRef]

99. Opdal, I.M.; Morseth, B.; Handegård, B.H.; Lillevoll, K.; Ask, H.; Nielsen, C.S.; Horsch, A.; Furberg, A.-S.; Rosenbaum, S.; Rognmo, K. Change in physical activity is not associated with change in mental distress among adolescents: The Tromsø study: Fit Futures. BMC Public Health 2019, 19, 1-11. [CrossRef]

100. Gerber, M.; Best, S.; Meerstetter, F.; Isoard-Gautheur, S.; Gustafsson, H.; Bianchi, R.; Madigan, D.J.; Colledge, F.; Ludyga, S.; Holsboer-Trachsler, E.; et al. Cross-Sectional and Longitudinal Associations Between Athlete Burnout, Insomnia, and Polysomnographic Indices in Young Elite Athletes. J. Sport Exerc. Psychol. 2018, 40, 312-324. [CrossRef]

101. Gerber, M.; Best, S.; Meerstetter, F.; Walter, M.; Ludyga, S.; Brand, S.; Bianchi, R.; Madigan, D.J.; Isoard-Gautheur, S.; Gustafsson, $\mathrm{H}$. Effects of stress and mental toughness on burnout and depressive symptoms: A prospective study with young elite athletes. J. Sci. Med. Sport 2018, 21, 1200-1205. [CrossRef] [PubMed]

102. Beck, N.M. Mental Toughness: An Analysis of Sex, Race, and Mood; University of North Texas: Denton, TX, USA, 2012.

103. Brand, S.; Gerber, M.; Kalak, N.; Kirov, R.; Lemola, S.; Clough, P.J.; Pühse, U.; Holsboer-Trachsler, E. "Sleep Well, Our Tough Heroes!"-In Adolescence, Greater Mental Toughness is Related to Better Sleep Schedules. Behav. Sleep Med. 2013, 12, 444-454. [CrossRef] 
104. Brand, S.; Gerber, M.; Kalak, N.; Kirov, R.; Lemola, S.; Clough, P.J.; Pühse, U.; Holsboer-Trachsler, E. Adolescents with Greater Mental Toughness Show Higher Sleep Efficiency, More Deep Sleep and Fewer Awakenings After Sleep Onset. J. Adolesc. Health 2014, 54, 109-113. [CrossRef] [PubMed]

105. Brand, S.; Kalak, N.; Gerber, M.; Clough, P.J.; Lemola, S.; Pühse, U.; Holsboer-Trachsler, E. During early and mid-adolescence, greater mental toughness is related to increased sleep quality and quality of life. J. Health Psychol. 2016, 21, 905-915. [CrossRef]

106. Bull, S.J.; Shambrook, C.J.; James, W.; Brooks, J.E. Towards an Understanding of Mental Toughness in Elite English Cricketers. J. Appl. Sport Psychol. 2005, 17, 209-227. [CrossRef]

107. Jones, G.; Hanton, S.; Connaughton, D. A Framework of Mental Toughness in the World's Best Performers. Sport Psychol. 2007, 21, 243-264. [CrossRef]

108. Coulter, T.J.; Mallett, C.J.; Gucciardi, D.F. Understanding mental toughness in Australian soccer: Perceptions of players, parents, and coaches. J. Sports Sci. 2010, 28, 699-716. [CrossRef]

109. Cowden, R.G.; Clough, P.J.; Asante, K.O. Mental Toughness in South African Youth. Psychol. Rep. 2017, 120, 271-289. [CrossRef]

110. Crust, L. Mental toughness in sport: A review. Int. J. Sport Exerc. Psychol. 2007, 5, 270-290. [CrossRef]

111. Gerber, M.; Brand, S.; Feldmeth, A.K.; Lang, C.; Elliot, C.; Holsboer-Trachsler, E.; Pühse, U. Adolescents with high mental toughness adapt better to perceived stress: A longitudinal study with Swiss vocational students. Pers. Individ. Differ. 2013, 54, 808-814. [CrossRef]

112. Gerber, M.; Kalak, N.; Lemola, S.; Clough, P.J.; Pühse, U.; Elliot, C.; Holsboer-Trachsler, E.; Brand, S. Adolescents' exercise and physical activity are associated with mental toughness. Ment. Health Phys. Act. 2012, 5, 35-42. [CrossRef]

113. Levy, A.; Polman, R.C.; Clough, P.J.; Marchant, D.; Earle, K. Mental Toughness as a Determinant of Beliefs, Pain, and Adherence in Sport Injury Rehabilitation. J. Sport Rehabil. 2006, 15, 245-254. [CrossRef]

114. Lin, Y.; Mutz, J.; Clough, P.J.; Papageorgiou, K.A. Mental Toughness and Individual Differences in Learning, Educational and Work Performance, Psychological Well-being, and Personality: A Systematic Review. Front. Psychol. 2017, 8, 8. [CrossRef] [PubMed]

115. Bahmani, D.S.; Esmaeili, L.; Shaygannejad, V.; Gerber, M.; Kesselring, J.; Lang, U.E.; Holsboer-Trachsler, E.; Brand, S. Stability of Mental Toughness, Sleep Disturbances, and Physical Activity in Patients with Multiple Sclerosis (MS) - A Longitudinal and Pilot Study. Front. Psychiatry 2018, 9, 182. [CrossRef] [PubMed]

116. Brand, S.; Gerber, M.; Kalak, N.; Lemola, S.; Clough, P.J.; Calabrese, P.; Shaygannejad, V.; Pühse, U.; Holsboer-Trachsler, E.; Bahmani, D.S. Mental toughness, sleep disturbances, and physical activity in patients with multiple sclerosis compared to healthy adolescents and young adults. Neuropsychiatr. Dis. Treat. 2016, 12, 1571-1579. [CrossRef]

117. Stamp, E.; Crust, L.; Swann, C.; Perry, J.; Clough, P.; Marchant, D. Relationships between mental toughness and psychological wellbeing in undergraduate students. Pers. Individ. Differ. 2015, 75, 170-174. [CrossRef]

118. Thelwell, R.C.; Weston, N.; Greenlees, I. Defining and Understanding Mental Toughness within Soccer. J. Appl. Sport Psychol. 2005, 17, 326-332. [CrossRef]

119. Clough, P.; Earle, K.; Sewell, D. Mental toughness: The concept and its measurement. Solut. Sport Psychol. $2002,32-43$.

120. Crust, L. A review and conceptual re-examination of mental toughness: Implications for future researchers. Pers. Individ. Differ. 2008, 45, 576-583. [CrossRef]

121. Crust, L.; Earle, K.; Perry, J.; Earle, F.; Clough, A.; Clough, P.J. Mental toughness in higher education: Relationships with achievement and progression in first-year university sports students. Pers. Individ. Differ. 2014, 69, 87-91. [CrossRef]

122. Crust, L.; Azadi, K. Mental toughness and athletes' use of psychological strategies. Eur. J. Sport Sci. 2010, 10, 43-51. [CrossRef]

123. Bahmani, D.S.; Hatzinger, M.; Gerber, M.; Lemola, S.; Clough, P.J.; Perren, S.; von Klitzing, K.; von Wyl, A.; Holsboer-Trachsler, E.; Brand, S. The Origins of Mental Toughness-Prosocial Behavior and Low Internalizing and Externalizing Problems at Age 5 Predict Higher Mental Toughness Scores at Age 14. Front. Psychol. 2016, 7, 1221. [CrossRef]

124. Liew, G.C.; Kuan, G.; Chin, N.S.; Hashim, H.A. Mental toughness in sport. Ger. J. Exerc. Sport Res. 2019, 49, 381-394. [CrossRef]

125. Tibbert, S.J. Mental Toughness and Overtraining Behaviours; Victoria University: Melbourne, Australia, 2013.

126. Brand, S.; Sabouri, S.; Gerber, M.; Bahmani, D.S.; Lemola, S.; Clough, P.; Kalak, N.; Shamsi, M.; Holsboer-Trachsler, E. Examining Dark Triad traits in relation to mental toughness and physical activity in young adults. Neuropsychiatr. Dis. Treat. 2016, 12, 229-235. [CrossRef] [PubMed]

127. Onley, M.; Veselka, L.; Schermer, J.A.; Vernon, P.A. Survival of the Scheming: A Genetically Informed Link between the Dark Triad and Mental Toughness. Twin Res. Hum. Genet. 2013, 16, 1087-1095. [CrossRef] [PubMed]

128. Papageorgiou, K.A.; Benini, E.; Bilello, D.; Gianniou, F.-M.; Clough, P.J.; Costantini, G. Bridging the gap: A network approach to Dark Triad, Mental Toughness, the Big Five, and perceived stress. J. Pers. 2019, 87, 1250-1263. [CrossRef] [PubMed]

129. Renton, T.; Petersen, B.; Kennedy, S. Investigating correlates of athletic identity and sport-related injury outcomes: A scoping review. BMJ Open 2021, 11, e044199. [CrossRef]

130. Kalak, N.; Gerber, M.; Kirov, R.; Mikoteit, T.; Yordanova, J.; Pühse, U.; Holsboer-Trachsler, E.; Brand, S. Daily Morning Running for 3 Weeks Improved Sleep and Psychological Functioning in Healthy Adolescents Compared With Controls. J. Adolesc. Health 2012, 51, 615-622. [CrossRef]

131. Brand, S.; Kalak, N.; Gerber, M.; Kirov, R.; Pühse, U.; Holsboer-Trachsler, E. High self-perceived exercise exertion before bedtime is associated with greater objectively assessed sleep efficiency. Sleep Med. 2014, 15, 1031-1036. [CrossRef] 
132. Brand, S.; Beck, J.; Gerber, M.; Hatzinger, M.; Holsboer-Trachsler, E. Evidence of favorable sleep-EEG patterns in adolescent male vigorous football players compared to controls. World J. Biol. Psychiatry 2009, 11, 1-11. [CrossRef]

133. Brand, S.; Beck, J.; Gerber, M.; Hatzinger, M.; Holsboer-Trachsler, E. 'Football is good for your sleep': Favorable sleep patterns and psychological functioning of adolescent male intense football players compared to controls. J. Health Psychol. 2009, 14, 1144-1155. [CrossRef]

134. Buman, M.; Phillips, B.A.; Youngstedt, S.D.; Kline, C.E.; Hirshkowitz, M. Does nighttime exercise really disturb sleep? Results from the 2013 National Sleep Foundation Sleep in America Poll. Sleep Med. 2014, 15, 755-761. [CrossRef]

135. Lang, C.; Brand, S.; Feldmeth, A.K.; Holsboer-Trachsler, E.; Pühse, U.; Gerber, M. Increased self-reported and objectively assessed physical activity predict sleep quality among adolescents. Physiol. Behav. 2013, 120, 46-53. [CrossRef]

136. Lang, C.; Kalak, N.; Brand, S.; Holsboer-Trachsler, E.; Pühse, U.; Gerber, M. The relationship between physical activity and sleep from mid adolescence to early adulthood. A systematic review of methodological approaches and meta-analysis. Sleep Med. Rev. 2016, 28, 32-45. [CrossRef] [PubMed]

137. Holfeld, B.; Ruthig, J.C. A Longitudinal Examination of Sleep Quality and Physical Activity in Older Adults. J. Appl. Gerontol. 2012, 33, 791-807. [CrossRef] [PubMed]

138. Chennaoui, M.; Arnal, P.J.; Sauvet, F.; Léger, D. Sleep and exercise: A reciprocal issue? Sleep Med. Rev. 2015, 20, 59-72. [CrossRef] [PubMed]

139. Gillis, B.; El-Sheikh, M. Sleep and adjustment in adolescence: Physical activity as a moderator of risk. Sleep Health $2019,5,266-272$. [CrossRef] [PubMed]

140. Kredlow, M.A.; Capozzoli, M.C.; Hearon, B.A.; Calkins, A.W.; Otto, M. The effects of physical activity on sleep: A meta-analytic review. J. Behav. Med. 2015, 38, 427-449. [CrossRef] [PubMed]

141. World Medical Association. World Medical Association Declaration of Helsinki. Ethical principles for medical research involving human subjects. JAMA 2013, 310, 2191-2194. [CrossRef] [PubMed]

142. First, M.B. Structured Clinical Interview for theDSM(SCID). Encycl. Clin. Psychol. 2015, 1-6. [CrossRef]

143. American Psychiatric Association. Diagnostic and Statistical Manual of Mental Disorders, 5th ed.; American Psychiatric Association: Arlington, VA, USA, 2013.

144. Nourbala, A.A.; Bagheri Yazdi, S.A.; Mohammad, K. The validation of the General Health Questionnaire-28 as a psychiatric screening tool. Hakim Res. J. 2009, 11, 47-53.

145. Goldberg, D.P.; Hillier, V.F. A scaled version of the General Health Questionnaire. Psychol. Med. 1979, 9, 139-145. [CrossRef]

146. Jahangard, L.; Rahmani, A.; Haghighi, M.; Ahmadpanah, M.; Bahmani, D.S.; Soltanian, A.R.; Shirzadi, S.; Bajoghli, H.; Gerber, M.; Holsboer-Trachsler, E.; et al. "Always Look on the Bright Side of Life!"- Higher Hypomania Scores Are Associated with Higher Mental Toughness, Increased Physical Activity, and Lower Symptoms of Depression and Lower Sleep Complaints. Front. Psychol. 2017, 8, 2130. [CrossRef]

147. Perry, J.L.; Clough, P.J.; Crust, L.; Earle, K.; Nicholls, A.R. Factorial validity of the Mental Toughness Questionnaire-48. Pers. Individ. Differ. 2013, 54, 587-592. [CrossRef]

148. Khalili, R.; Nir, M.S.; Ebadi, A.; Tavallai, A.; Habibi, M. Validity and reliability of the Cohen 10-item Perceived Stress Scale in patients with chronic headache: Persian version. Asian J. Psychiatry 2017, 26, 136-140. [CrossRef] [PubMed]

149. Maroufizadeh, S.; Zareiyan, A.; Sigari, N. Reliability and validity of Persian version of perceived stress scale (PSS-10) in adults with asthma. Arch. Iran. Med. 2014, 17, 361-365.

150. Cohen, S.; Kamarck, T.; Mermelstein, R. A global measure of perceived stress. J. Health Soc. Behav. 1983, 24, 385-396. [CrossRef] [PubMed]

151. Chehri, A.; Brand, S.; Goldaste, N.; Eskandari, S.; Brühl, A.; Bahmani, D.S.; Khazaie, H. Psychometric Properties of the Persian Pittsburgh Sleep Quality Index for Adolescents. Int. J. Environ. Res. Public Health 2020, 17, 7095. [CrossRef]

152. Chehri, A.; Nourozi, M.; Eskandari, S.; Khazaie, H.; Hemati, N.; Jalali, A. Validation of the Persian version of the Pittsburgh Sleep Quality Index in elderly population. Sleep Sci. 2020, 13, 119-124. [CrossRef]

153. Moghaddam, J.F.; Nakhaee, N.; Sheibani, V.; Garrusi, B.; Amirkafi, A. Reliability and validity of the Persian version of the Pittsburgh Sleep Quality Index (PSQI-P). Sleep Breath. 2012, 16, 79-82. [CrossRef]

154. Khosravifar, S.; Bandi, M.G.; Alavi, K.; Javadi, P.H.S. Evaluation of the psychometric properties of the Persian version of the Pittsburgh Sleep Quality Index in depressed patients. Electron. Physician 2015, 7, 1644-1652. [CrossRef] [PubMed]

155. Nazifi, M.; Mokarami, H.; Akbaritabar, A.; Kalte, H.O.; Rahi, A. Psychometric Properties of the Persian Translation of Pittsburgh Sleep Quality Index. Health Scope 2014, 3, 15547. [CrossRef]

156. Buysse, D.J.; Reynolds, C.F., 3rd; Monk, T.H.; Berman, S.R.; Kupfer, D.J. The Pittsburgh Sleep Quality Index: A new instrument for psychiatric practice and research. Psychiatry Res. 1989, 28, 193-213. [CrossRef]

157. Brosius, F. SPSS: Umfassendes Handbuch zu Statistik und Datenanalyse-Comprehensive Textbook for Statistics and Data Analysis; Mitp Verlags GmBH \& Co.: Frechen, Germany, 2018.

158. Hair, J.F.; Black, C.W.; Babin, B.J.; Anderson, R.E. Multivariate Data Analysis, 7th ed.; Pearson Education Limited: London, UK, 2014.

159. Rudolf, M.; Müller, J. Multivariate Analyses; Hogrefe: Goettingen, Germany, 2004.

160. Aiken, L.S.; West, S.G. Multiple Regression: Testing and Interpreting Interactions; Sage Publications: Thousand Oaks, CA, USA, 1991.

161. Cohen, J. A power primer. Psychol. Bull. 1992, 112, 155-159. [CrossRef] 
162. Cohen, J. Statistical Power Analysis for the Behavioral Sciences, 2nd ed.; Routledge Academic: New York, NY, USA, 1988.

163. Jaiswal, S.; Shashikala, K.T. A Comparative Study of Sleep Quality in Athletes \& Non Athletes. Int. J. Physiol. 2020, 8, 162-166. [CrossRef]

164. Demirel, H. Sleep Quality Differs Between Athletes and Non-athletes. Clin. Investig. Med. 2016, 39, 184-186. [CrossRef]

165. Hoshikawa, M.; Uchida, S.; Hirano, Y. A Subjective Assessment of the Prevalence and Factors Associated with Poor Sleep Quality Amongst Elite Japanese Athletes. Sports Med.-Open 2018, 4, 1-13. [CrossRef]

166. Nedelec, M.; Aloulou, A.; Duforez, F.; Meyer, T.; Dupont, G. The Variability of Sleep Among Elite Athletes. Sports Med.-Open 2018, 4, 34. [CrossRef] [PubMed]

167. MacLaren, V.V.; Best, L. Symptoms of Exercise Dependence and Physical Activity in Students. Percept. Mot. Ski. 2007, 105, 1257-1264. [CrossRef] [PubMed]

168. Steele, I.H.; Pope, H.G.; Kanayama, G. Competitive Bodybuilding: Fitness, Pathology, or Both? Harv. Rev. Psychiatry 2019, 27, 233-240. [CrossRef]

169. Costa, S.; Hausenblas, H.A.; Oliva, P.; Cuzzocrea, F.; Larcan, R. Maladaptive perfectionism as mediator among psychological control, eating disorders, and exercise dependence symptoms in habitual exerciser. J. Behav. Addict. 2016, 5, 77-89. [CrossRef]

170. Wågan, F.; Darvik, M.; Pedersen, A. Associations between Self-Esteem, Psychological Stress, and the Risk of Exercise Dependence. Int. J. Environ. Res. Public Health 2021, 18, 5577. [CrossRef] [PubMed]

171. Flockhart, M.; Nilsson, L.C.; Tais, S.; Ekblom, B.; Apró, W.; Larsen, F.J. Excessive exercise training causes mitochondrial functional impairment and decreases glucose tolerance in healthy volunteers. Cell Metab. 2021, 33, 957-970.e6. [CrossRef] [PubMed]

172. Pataky, M.W.; Nair, K.S. Too much of a good thing: Excess exercise can harm mitochondria. Cell Metab. 2021, 33, 847-848. [CrossRef] [PubMed]

173. Master, L.; Nye, R.T.; Lee, S.; Nahmod, N.G.; Mariani, S.; Hale, L.; Buxton, O.M. Bidirectional, Daily Temporal Associations between Sleep and Physical Activity in Adolescents. Sci. Rep. 2019, 9, 7732. [CrossRef]

174. Stults-Kolehmainen, M.A.; Sinha, R. The Effects of Stress on Physical Activity and Exercise. Sports Med. 2014, 44, 81-121. [CrossRef] [PubMed]

175. Sani, S.H.Z.; Fathirezaie, Z.; Brand, S.; Pühse, U.; Holsboer-Trachsler, E.; Gerber, M.; Talepasand, S. Physical activity and self-esteem: Testing direct and indirect relationships associated with psychological and physical mechanisms. Neuropsychiatr. Dis. Treat. 2016, 12, 2617-2625. [CrossRef] [PubMed]

176. Sani, S.H.Z.; Fathirezaie, Z.; Gerber, M.; Pühse, U.; Bahmani, D.S.; Bashiri, M.; Pourali, M.; Brand, S. Self-Esteem and Symptoms of Eating-Disordered Behavior Among Female Adolescents. Psychol. Rep. 2021, 10, 1515-1538. [CrossRef] [PubMed] 